Global Journal of Human Resource Management

Vol.8, No.2, pp.1-32, June 2020

Published by ECRTD-UK

Print ISSN: 2053-5686(Print), Online ISSN: 2053-5694(Online)

\title{
HUMAN RESOURCE FOR HEALTH MANAGEMENT PRACTICES ON TRAINING AND DEVELOPMENT BETWEEN SECONDARY AND TERTIARY HEALTHCARE FACILITIES IN CROSS RIVER STATE AND EBONYI STATE
}

\author{
${ }^{1}$ Dr. Lukpata, H. Ogar \\ Department of Public Health, Faculty of Allied Medical Sciences, University of Calabar, \\ Calabar, Nigeria. \\ ${ }^{2}$ Dr. Lukpata, F. Ekwok \\ Department of Nursing Science, Faculty of Allied Medical sciences, University of Calabar, \\ Calabar, Nigeria. \\ ${ }^{3}$ Dr. Eze Aji Eze \\ Department of Health Information Management, College of Health Technology, Calabar, Nigeria \\ ${ }^{3}$ Dr. Glory Mbe Egom Nja \\ Department of Public Health, Faculty of Allied Medical Sciences, University of Calabar, \\ Calabar, Nigeria. \\ ${ }^{4}$ Prof. A. Adindu \\ Department of Public Health, Faculty of Allied Medical Sciences, University of Calabar, \\ Calabar, Nigeria.
}

\begin{abstract}
The study investigate human resource for health management practices on training and development between secondary and tertiary healthcare facilities. The study adopted a descriptive research design. The independent t-test analysis showed that the calculated t-value of 2.412 was greater than the critical t-value of 1.96 at 0.05 alpha level of significance. Specifically, on in-service training, $35.7 \%$ and $19.7 \%$ of secondary healthcare respondents reported not practiced and practiced to a little extent respectively. This shows significant differences from responses in the tertiary healthcare facilities with only $17.6 \%$ and $21.3 \%$ respectively reported corresponding responses (that is, negative responses of $55.4 \%$ and $38.9 \%$ for secondary and tertiary respectively). This observed trend in the secondary healthcare facilities was affirmed by qualitative responses where secondary level respondents verbalized non provision for in-service training. However, in both States, secondary healthcare facilities key informants affirmed the assistance and role of development partners in staff training and development but that such trainings are in their (partners') area of interest/interventions. It was recommended that bi-annual training, retraining and development of the health workforce should be made an area of utmost priority particularly at the secondary level of care. This is important considering the paucity in stock of HRH and emerging challenges emanating from the trend of disease outbreaks and occurrence.
\end{abstract}

KEYWORDS: human resource, health management practices, training and development, secondary and tertiary healthcare facilities, cross river state and Ebonyi state. 
Global Journal of Human Resource Management

Vol.8, No.2, pp.1-32, June 2020

Published by ECRTD-UK

Print ISSN: 2053-5686(Print), Online ISSN: 2053-5694(Online)

\section{INTRODUCTION}

\section{Background to the study}

Human Resource for Health is one of the most important resources required in the health sector. They are the corner stone of the healthcare delivery system as they determine access to healthcare, quality of healthcare services and to a great extent, the success of any healthcare programme. Despite the glaring importance of human resource for health, challenges in adequacy and mix of HRH prevail globally and in Nigeria. The International Labor Organization (ILO) posits that globally 10.3 million additional health workers are required to close the current gaps to ensure the delivery of universal healthcare. The shortage of HRH is more worrisome in developing countries, mainly in Asia where 7.1 million and in Africa 2.8 million trained health workers are needed (ILO, 2014).

In Nigeria, the poor performance of the entire healthcare system has been attributed to several factors with the challenge of Human Resource for Health as a major contributor (Uneke et al., 2007). The HRH challenges in Nigeria are widespread however, the challenges differ between zones and States; and between rural and urban dwellings. The pervasive shortage of human resource for health has affected negatively the implementation of health programmes, quality of healthcare services and is a major cause of prolonged waiting time in health facilities (PRRINNMNCH, 2014; O’Neill, Edim \& Obarein, 2014; Salami et al., 2016.).In Cross River and Ebonyi States, Human Resource for Health constraints have been identified as a huge challenge to the effective functioning of the health sector and has been implicated as the major cause of failure of laudable health programmes such as HIV/AIDS interventions, immunizations and free maternal and child healthcare services (Cross River State Agency for control of HIV/AIDS, 2013; Uneke et al., 2014; Oku et al., 2017). Major gaps related to the health workforce include inadequate number of health personnel, inappropriate distribution of trained personnel, de-motivated health workforce, high attrition of health workers and staff lost as health professionals migrate to other health institutions, States and developed countries in search of greener pastures (Cross River State Ministry of Health, 2015).

Several factors have been identified as contributing to the Human Resource for Health challenges in Nigeria. Among these factors interestingly is the failure in implementation of Human Resource for Health Management practices resulting in de-motivated health workforce, high attrition and migration experienced at all levels (Uneke et al., 2007; Fajana, Owoyemi, Elegbede \& Sheriff, 2011: Omoluabi, 2014). Strong positive ties exist between effective HRM practices and workers motivation, retention, job performance, success of health programmes and a viable tool for achieving sustainable solutions to the HRH challenges (Mugo, Nyandika \& Okibo, 2014; Jaskiewiez et al., 2015)What then are the Human Resource Management practices in Cross River and Ebonyi States? This question prompted this study which investigates Human Resource for Health Management Practices at secondary and tertiary healthcare facilities in Cross River and Ebonyi States. Specifically the study assessed availability of HRH policies and documents; investigates Human Resource for Health Management practices on planning; recruitment and 
Global Journal of Human Resource Management

Vol.8, No.2, pp.1-32, June 2020

Published by ECRTD-UK

Print ISSN: 2053-5686(Print), Online ISSN: 2053-5694(Online)

deployment; training and development; retention; workplace safety and security; performance management and human resources information systems.

This paper aim to identify various gaps or challenges in human resource for health management practices on training and development in both secondary and health care facilities. In Nigeria, several challenges have been reported within the health sector especially in funding as regards training and development of the health workforce (Adeloye, et al, 2017; Adindu \& Asuquo, 2013). Few researches on HRH has been carried out in both Ebonyi and Cross River state, however, no comparative study have been carried out to identify disparity in training and development practices between Ebonyi and Cross River State and between Secondary and Tertiary healthcare facilities. This paper has specifically revealed that in Cross River and Ebonyi State Secondary health facilities, in-service training is basically carried out in collaboration with Development Partners. Therefore, opportunity for training is dependent on areas of interest and intervention of the sponsoring body (Development Partners) and may not be the healthcare facilities area of need. This is conspicuously different in the tertiary level where staff are only trained in the identified areas of healthcare facility needs. The disparity revealed by this study is significant as both tertiary and secondary facilities serve the same population and therefore need technically competent health workforce that meet the needs of the people.

\section{LITERATURE REVIEW}

Human resource for health management practices on training and development

WHO estimates that an additional 4.3 million health workers are needed worldwide to meet the healthcare needs of the world population. The lingering human resource for health crisis has detrimental effect on the health and wellbeing of millions of people, yet the production of the health professionals is not adequate to close this shortfall (WHO, 2016). This challenge therefore demands that production of healthcare professionals through trainings (pre-service, in service and post-basic) should be made a priority. In order to increase health workforce population, enhance productivity and performance of employees, trainings of different kinds including pre-service and in-service trainings and development are required to equip healthcare professionals with the necessary skills for service delivery. To ensure this, the responsibility of updating staff knowledge and skill has to be discharged by HR Managers in a competent way (Alemu et al., 2011). Kabene et al., (2006) posit that a properly trained and competent workforce is essential to any successful healthcare system.

Training is viewed as the systematic acquisition and development of the knowledge, skills, and attitudes required by employees to adequately perform an assigned job or task to boost performance in the job environment. Trainings carried out should be able to equip the employee with new knowledge and skills that are relevant to the assigned task; training should meet employee and organizational needs and, should be efficiently and effectively designed and delivered (Hong, Hao, Kumar, Ramendran \& Kadiresan, 2012). Hong et al. again assert that, when the results of training reflected in improvements in relevant knowledge and the acquisition of relevant skills manifest, employee job performance should improve provided that the skills learned in training are transferred to the job. Training outcomes should reflect in improved performance 
Global Journal of Human Resource Management

Vol.8, No.2, pp.1-32, June 2020

Published by ECRTD-UK

Print ISSN: 2053-5686(Print), Online ISSN: 2053-5694(Online)

such as increase productivity and improved quality of services. The glaring importance of human resource makes it imperative for each society, even some of the poorest to invest important in training the required human resources (Hong et al.2012). According to WHO (2016) scaling up training programmes to produce multi-disciplinary service delivery teams which include carefully balanced mix of clinicians, community health workers and health managers is clearly urgent and essential (WHO, 2016). However, the challenge of human resource for health is not limited to simply increasing the numbers of workers but being concerned on their mix and competencies. Human resource for health challenges are worsened by the fact that their skills, competencies, clinical experience and expectations are often poorly suited to the health needs of the populations they serve. Increasing the quantity and improving the quality and relevance of health workers to meet the needs of the $21^{\text {st }}$ century and contribute to better population health outcomes require implementation of the health policy on training (WHO, 2016).

Appropriate training and skill development lapses are glaring in Nigeria. Some of the gaps in HRH training highlighted by Adindu and Asuquo (2013) include uneven distribution of training institutions with $75 \%$ of medical schools situated in the southern part of the country; some health professionals training institutions produce too many of some categories who cannot be adequately absorbed within the environment and under produce other critically needed categories; absence of health service management in the content of training schools curricula; training of doctors, nurses and other professionals are highly clinical and curative oriented with skills beyond clinical competencies not integrated; training institutions rarely develop curricula based on the social, cultural realities and health needs of the people; clinical approaches and orientation of technologically developed countries dominate pre-service training in Nigeria; course content and mode of delivery or teaching remain unchanged even when topics are obsolete and no more relevant; each discipline fights for supremacy, students are indoctrinated and graduate with similar notion rendering health organizations dysfunctional (Adindu \& Asuquo, 2013) Labiran et al (2008) also identified some gaps contributing to the HRH challenges in Nigeria as limit placed on number of students to be admitted in health training institutions. They observed that the practice of limiting enrolment of students to fifty (50) in the health training institutions has a detrimental effect on the production of the necessary healthcare professionals.

On production and pre-service training, the National Human Resource for Health policy states that they shall be increase production of frontline caregivers such as Nurses/ midwives, community nurses and midwives and CHEWS in line with projected requirements. Some of the strategies outlined in the policy include; determining nurse/midwives and health workers needs over a period of 10 years; adequate budget allocation for training of the critically needed staff; building capacity of states or zonal training institutions in terms of infrastructure, equipment's and tutors; adjusting intakes into health training institutions regularly on the basis of projected requirement (FMOH, 2007). Also, to boost pre-service training and in addition to the other strategies, the policy identified the following strategies; training and retraining of administrators and tutors, States sponsoring candidates and bonding them to return to serve; encouraging establishment of community nursing/midwifery training institutions for the production of adequate number of community nurses and midwives; regular reviewing of training curricula and periodic introduction of new and relevant specialization courses (FMOH, 2006; FMOH, 2007). 
Global Journal of Human Resource Management

Vol.8, No.2, pp.1-32, June 2020

Published by ECRTD-UK

Print ISSN: 2053-5686(Print), Online ISSN: 2053-5694(Online)

To enhance the capacity of staff and ensure continuing professional development, some strategies were indicated which include; re-orienting postgraduate and post-basic programmes to the priority needs of the country; providing scholarship to trainees and staff in needed specialty and to bond them, and developing special bridging programmes of training which allow desirous technical grade health workers to progress. The policy also made provision for In-service training. The government in the policy also declared it commitment to expose healthcare professionals irrespective of workplace, cadre or category to frequent training updates in other to be abreast with current trends in healthcare, enhance their knowledge, skills and attitude in the performance of their assigned roles and responsibilities (FMOH, 2006; FMOH, 2007). However failure in this commitment seem to prevail as gaps in staff continuing education training and development have been reported by several studies. Adeloye, David, Olaogun, Auta, Adesokan and Gandanya et al. (2017) observed some challenges within the health sector in Nigeria especially in training, funding of programmes as well as financing trainings and development of the health workforce. They further reported that, there are no provisions for regular clinical training across several health facilities despite credit units needed from this for continuing professional development which is mandatory. Again, in Cross River State, Adebajo, Okereke, Friday (2017) reported that Nursing and Midwifery schools have not been fully accredited... and professional development for staff do not exist. In attempt to intervene in the challenges besieging the secondary healthcare sector/facilities, the FMOH in 2005 set up a committee to identify strategies for strengthening the secondary healthcare delivery system. Among the utmost challenges identified by the committee was lack of continuing education (capacity building) for the existing secondary healthcare workforce (FMOH, 2005). However, the intervention of Population Council a non-governmental development partner in Cross River State has led to improvement in In-service training and accreditation of schools of Nursing and Midwifery.

\section{METHODOLOGY}

\section{Study setting}

The settings for this research are Ebonyi State in the South-east and Cross River State in the Southsouth geopolitical zones of Nigeria. The south-east geopolitical zone consists of Abia, Anambra, Ebonyi, Enugu and Imo States while the south-south zone comprise of Akwa Ibom, Bayelsa, Cross River, Delta, Edo and Rivers States. The choice of the two States from two different geo-political zones whose findings reveal the prevailing $\mathrm{HRH}$ management practices provide room for comparison of findings across the zones. These differences include political will and commitment that may influence HRH management practices particularly in the secondary health facilities.

\section{Cross River State}

Cross River State is in the south-south geopolitical zone of Nigeria, with Calabar as the State capital. The present Cross River State came into being in 1987 when Akwa Ibom State was carved out of the old Cross River State (Cross River State Ministry of Health, 2010). It has eighteen local government areas with a projected 2006 population of 2,888,966, comprising 1,492,465 males and 1,396,501 females. There are 196 political wards in the State shared into three senatorial districts; south, central and northern senatorial districts (National Population Commission, 2009). The State 
Global Journal of Human Resource Management

Vol.8, No.2, pp.1-32, June 2020

Published by ECRTD-UK

Print ISSN: 2053-5686(Print), Online ISSN: 2053-5694(Online)

shares common boundaries with Cameroon Republic in the East, Benue State in the North, Ebonyi and Abia States in the West and the Atlantic Ocean and Akwa Ibom State in the south.

The people of Cross River are predominantly farmers and fishermen with a few petty traders and civil servants. The main sources of income are from federal subvention, income taxes from few companies and large quantities of limestone in Akamkpa LGA. It has a total landmass of about 23,000 square kilometers.

Health indices and healthcare delivery

The demographic data in Cross River State shows that women and children under five who are the most vulnerable, constitute $22 \%$ and $20 \%$ of the total population of the State respectively. Health indicators such as maternal mortality ratio (2000/100,000), under-five mortality (175/1000) and infant mortality (120/1000) rates which rank Cross River State amongst the States with the highest maternal and child death in Nigeria. Considering that women constitute $22 \%$ and under five children $20 \%$ of the total population of the State, these high mortality indicate that the healthcare services were inadequate (Cross River State Ministry of Health, 2010). Measures of access to healthcare services in the State show the following cove rages; antenatal care (68\%) births assisted by a skilled provider (44\%) births delivered in a health facility (39\%), percentage of children 12 23 months who are fully immunized (38\%), contraceptive prevalence rate (16.0\%) among others. The coverage of most interventions is too low to contribute any significant improvement in the health status of the people of the state (Cross River State Ministry of Health, 2010).

\section{Human resource for health}

The State has a total health workforce population of 3,367 personnel which include 363 doctors, 1,634 nurses/midwives, 5 dentists and 85 pharmacists. General Hospital Calabar alone has a total health workforce of about 293 health personnel (Cross River State Ministry of Health, 2015). Interestingly, the State has a Human Resource for Health Policy which was launched in September, 2017 (Cross River State Ministry of Health, 2017). The University of Calabar Teaching Hospital which is the only tertiary health facility in the State has a health workforce population of 1, 360 (University of Calabar Teaching Hospital: Human Resources Unit, 2017).

\section{Ebonyi State}

Ebonyi State was created on October $1^{\text {st }}, 1996$ from the present Enugu and Abia States with its headquarters at Abakaliki. It is bounded by Cross River State in the east, Enugu State in the west, Benue State in the north and Abia State in the south. The State has thirteen local government areas grouped into three senatorial districts namely, Ebonyi North comprising Abakaliki, Ebonyi, Ohaukwu and Izzi LGAs; Ebonyi central made up of Ishielu, Ikwo, Ezza North and Ezza South LGAs; and Ebonyi South made up of Afikpo North, Afikpo South, Ivo, Ohaozara and Onicha LGAs. Ebonyi State occupies approximately a land mass of 5,935 square kilometers with a population of 2, 176, 947 and is situated between latitude $5^{\circ} 40^{\prime}$ and $8^{\circ} 30^{\prime}$ (NPC, 2009). The population of the State is made up of $48.9 \%$ males and $51.1 \%$ females with an average population density of 286 persons per square kilometer. The State is mainly rural with about $75 \%$ of the population living in rural areas (Ebonyi State Ministry of Health, 2010). 
Global Journal of Human Resource Management

Vol.8, No.2, pp.1-32, June 2020

Published by ECRTD-UK

Print ISSN: 2053-5686(Print), Online ISSN: 2053-5694(Online)

The mainstay of the people of Ebonyi State is Agriculture with over $75 \%$ of the people engaged in farming and related activities. Some of the crops produced by the State includes yam, rice, cassava, groundnut and tree crops like palm produce (Ebonyi State Ministry of Health, 2010).

\section{Health indices and healthcare delivery}

The life expectancy at birth in Ebonyi State was 53.8 years for female and 52.6 years for males in 1991 but declined to 46 years for females and 45 years for males in 2006. Infant mortality rate (IMR) has remained high and is estimated at 99 per 1000 live births while the under-five mortality rate (U5MR) is 191 per 1000 live births; maternal mortality rate (MMR) in the State is one of the highest in the country with ratio of about 1500 per 100,000 population (Ebonyi State Ministry of Health, 2010).According to the Strategic Healthcare Development Plan (2010), the healthcare system in the State is extremely weak with the primary and secondary health care levels virtually collapsed. The State has one tertiary health facility which is the Federal Teaching Hospital Abakaliki (FETHA) located in the State capital. In addition, there is strong presence of mission hospitals and private for profit health facilities (especially in the State capital), and about $60 \%$ of health services in the State are provided by the mission hospitals (Ebonyi State Ministry of Health, 2010).

\section{Human resource for health}

According to Ebonyi State Ministry of Health (2015), Ebonyi State has a total of 1, 207 trained health personnel. The interventions within the human resource for health target the distributions of workforce which is currently skewed towards urban population. General Hospital Onueke situated in Ezza Local Government Area has a total of 15 health professionals while Federal Teaching Hospital Abakaliki has a population of 1,996 health personnel (Federal Teaching Hospital Abakaliki: Human Resource Unit, 2017). General hospital Onueke (GHO).Onueke General Hospital which is a secondary level of healthcare, was established in 1978 at the headquarters of the Ezzas in Ezza Local Government Area of Ebonyi State. The hospital was cited as a referral center for patients from Ezza Local Government Area Primary healthcare facilities. GHO comprises medical, nursing, medical laboratory, pharmacy, health information, and radiography and community health departments. It has a total number of 10 beds with patients' flow of 40, 000 in a year, and a total workforce of fifteen (15) health professionals (Ebonyi State Ministry of Health, 2017). 
Ebonyi State (study site)

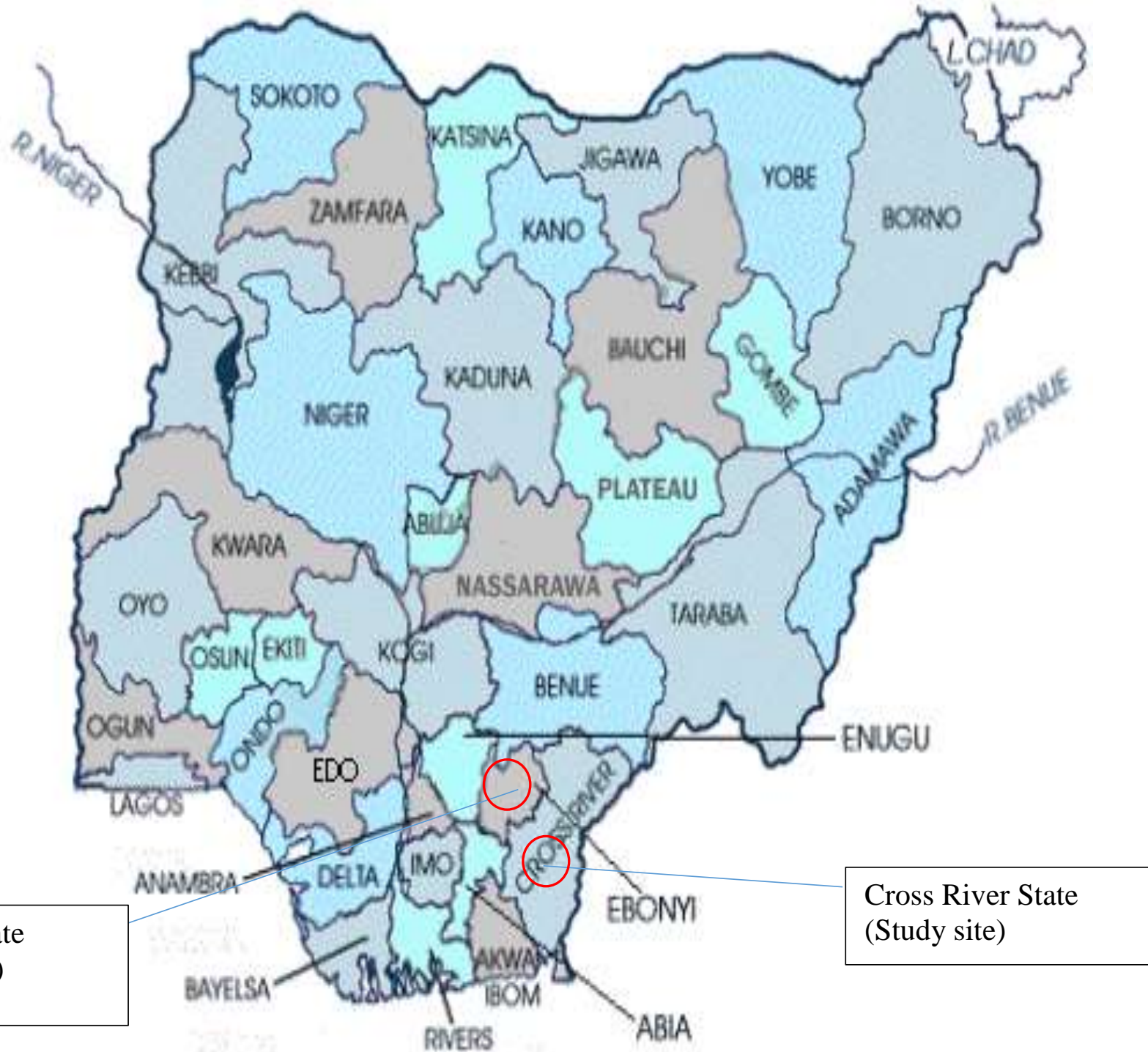

Map showing the study sites (Cross River and Ebonyi States).

PLATE. 1: Map indicating study sites

Adapted from http://ngex.com/nigeria/places

\section{Federal Teaching Hospital Abakaliki (FETHA)}

The Federal Teaching Hospital Abakaliki is a tertiary health institution in Abakaliki, Ebonyi State, dedicated to the provision of quality, accessible and affordable healthcare services with effective training and research services. It was created in the 1930s under the British Colonial administration with the name casualty control center. It was later changed from Casualty Control Center to Abakaliki General Hospital and then to Federal Medical Center (FMC). In 2011, FMC was upgraded to Federal Teaching Hospital Abakaliki, which was later merged in the same year with 
Global Journal of Human Resource Management

Vol.8, No.2, pp.1-32, June 2020

Published by ECRTD-UK

Print ISSN: 2053-5686(Print), Online ISSN: 2053-5694(Online)

Ebonyi State University Teaching Hospital (EBSUTH). From then on it came to be known as FETHA.

FETHA comprised medical, nursing, pharmacy, laboratory, physiotherapy, health information, radiology/radiography, dental and community health departments. It has a total number of 604 beds with patients' flow of 152,814 per year and a total workforce of 1,996 health professionals (Federal Teaching Hospital: Human Resource Unit, 2017).

\section{General Hospital Calabar (GHC)}

General Hospital Calabar is a secondary level of healthcare situated in Calabar South Local Government Area of Cross River State. It was established in the year 1992.

The hospital has the following departments; medical, nursing, pharmacy, medical laboratory, health information, radiography and community health departments. General hospital Calabar has available beds of 135 with patients' flow of 19, 793 per year and a total workforce of 293 health professionals (Cross River State Ministry of Health, 2017).

\section{University of Calabar Teaching Hospital (UCTH)}

UCTH was established in 1897 as St. Margaret's hospital located at Old Government Hill in the present day Calabar South LGA by the British colonial Government. In 1980 the hospital formally assumed it status as UCTH. Also, it was during this time that the contract for the construction of the permanent site was awarded and work commenced on the project. In the year 2000, UCTH moved to its permanent site in Calabar Municipal Council (Erim, \& Ndoma-Egba, 1998). UCTH comprises the following Departments; medical, nursing, pharmacy, medical laboratory, radiology/radiography, health information, physiotherapy, dental and community health departments. It has 615 available beds with patients' flow of 156, 049 per year and a total health workforce of 1, 360 health professionals (University of Calabar Teaching Hospital: Human Resource Unit, 2017).

\section{Study design}

A descriptive cross sectional design was adopted for this study to investigate Human Resource for Health Management Practices in the secondary and tertiary healthcare delivery system. This study generated quantitative and qualitative data using diverse instruments such as observational checklist, questionnaire, and key informant interview schedule.

\section{Study population}

The population of the study consist of health professionals from the secondary and tertiary levels of healthcare facilities of two States. Ebonyi State had a total health workforce population of 1, 207 personnel while Cross River State had a total of 3, 367 health professionals in the secondary healthcare facilities (Ebonyi State ministry of Health, 2015; Cross River State Ministry of Health, 2015). Similarly, Ebonyi tertiary healthcare facility had a population of 1, 996, while that of Cross River State was 1,360. This health workforce, from secondary and tertiary health facilities consisting of medical doctors, dentists, nurses, midwives, laboratory scientists/technicians, health recorders, radiographers/radiologists, pharmacist/technicians and community health workers form the target population. In the State, Directors of administration in General hospitals, Directors' in- 
Global Journal of Human Resource Management

Vol.8, No.2, pp.1-32, June 2020

Published by ECRTD-UK

Print ISSN: 2053-5686(Print), Online ISSN: 2053-5694(Online)

charge of Planning Research and Statistics (PRS) department and HRH focal persons in the State Ministries of health formed the key informant population. Again, in Teaching Hospitals, Directors of Administration and focal persons for human resource for health formed the key informants' respondents. These respondents are in a better position to supply dependable information on HRH management practices.

\section{Sample size determination}

\section{Sample size determination for quantitative data}

To determine the sample size for quantitative data, Taro Yamane's formula as cited in Sarmah, Hazarika \& Choudhury (2013) was adopted. It assumes 95\% confidence level

$(\mathrm{P}=.5)$. The computation of the formula is presented below:

Where $\quad \mathrm{n} \quad=$ the sample size

$$
\stackrel{\mathrm{N}}{1+\mathrm{N}}(\mathrm{e})^{2}
$$

$\mathrm{N} \quad=$ the population size

e $\quad=$ level of significance (precision) $(0.05)$

$1=$ constant

For Ebonyi State:

$$
\begin{aligned}
& \mathrm{n} \quad=\quad \frac{\mathrm{N}}{1+\mathrm{N}(\mathrm{e})^{2}} \\
& \mathrm{~N}=\quad 1207+1996=3203 \\
& =\underline{3203} \\
& 9.0075=355.59+35.56(10 \% \text { non- response })
\end{aligned}
$$

$$
\text { Total }=390.15=391 \text { respondents }
$$

For Cross River State:

$$
\begin{aligned}
\mathrm{n}= & \begin{array}{l}
\mathrm{N} \\
1+\mathrm{N}(\mathrm{e})^{2}
\end{array} \\
\mathrm{~N} \quad & \begin{array}{c}
3367+1360=4727 \\
1+(4727 \times 0.05)^{2}
\end{array} \\
=\frac{4727}{12.8175}=368.79+36.9(10 \% \text { non- response }) & \text { Total }=404.69=\mathbf{4 0 5} \text { respondents }
\end{aligned}
$$

Therefore, Ebonyi and Cross River State had $391+405=796$ respondents.

Based on the above formula, the sample size for this study (Ebonyi and Cross River States health professionals combined) consisted of 796 respondents drawn from both secondary and tertiary health facilities in the study area. 
Global Journal of Human Resource Management

Vol.8, No.2, pp.1-32, June 2020

Published by ECRTD-UK

Print ISSN: 2053-5686(Print), Online ISSN: 2053-5694(Online)

\section{Sample size determination for qualitative data}

Key informants consisted of persons who were in a better position to provide valuable information on policies and implementation of these policies as regards Human Resource for Health Management practices in the two levels of care investigated. Although, data saturation is considered to be a critical factor in the determination of sample size in qualitative studies (Dworkin, 2012), this study employed information power as the selected key informants were in a better position to provide valuable information on Human Resource for Health policies and implementation at both levels. Therefore, the total sample size for the key informant interview were ten (10).

\section{Sampling procedure}

This study was conducted in Cross River and Ebonyi States in the South-south and South-east of Nigeria respectively. To make provision for adequate representation of the population in the sample, different sampling approaches were adopted at different stages.

First stage: selection of hospitals. Two sampling techniques were used at this stage - simple random and purposive sampling approaches. Simple random sampling approach was used to select one General hospital from the list of General Hospitals in both States. Here, the names of all the General Hospitals in the two States were written in pieces of papers, folded and put into two containers (one for each State) and papers mixed adequately. One paper ball was picked from each of the two containers randomly. In this way, the two General Hospitals were picked. Also, given that each of these States has only one Teaching hospital, the Teaching hospitals were purposively picked for the study.

Second stage: selection of departments. The entire population of health professionals in the facilities for study were clustered into departments based on their distinct professional characteristics. The researcher purposively selected health oriented departments which were nine (9). These departments were medical, nursing, medical laboratory, pharmacy, physiotherapy, radiology/radiography, health information, dental and community health. Each department had equal quota of respondants based on the sample size for each facility

Third stage: selection of respondents. Convinience sampling technique was used in selecting respondents at the various health facilities except for General Hospital Onueke where the entire population of fifteen 15(3.8\%) of the sample for Ebonyi State were used. For each department, it was visited several times until the respondents (quota) for that department is reached. In FETHA, three hundred and seventy six (376) health professionals (96.2\%) of the sample size were administered the questionnaire to make up for Ebonyi State sample size of three hundred and ninety one (391). Thus, forty two (42) respondents (11.2\%) each were selected from seven (7) departments while forty one (41) respondents (11\%) each from two departments to ensure that respondents were selected fairly from each department.

In Cross River State, sixty (60\%) of respondants - two hundred and forty three (243) were drawn from the Teaching Hospital while forty (40\%), one hundred and sixty two (162) respondents were drawn from the General Hospital Calabar. Therefore, in UCTH, twenty seven (27) respondents 
Global Journal of Human Resource Management

Vol.8, No.2, pp.1-32, June 2020

Published by ECRTD-UK

Print ISSN: 2053-5686(Print), Online ISSN: 2053-5694(Online)

$(11.11 \%)$ from each department were administered the questionnaire while in General Hospital Calabar, twenty three (23) health professionals from six departments and twenty four (24) from one (1) department were administerd the questionnaire. To respond to the instrument on planning practices, nine (9) departmental heads corresponding with the nine departments in each facility were purposively selected. In this way, 405 respondents including departmental managers were drawn in Cross River and 391 respondents including departmental managers from Ebonyi States.

However, during the sorting and coding, some questionnaires were not eligible for entry due to incomplete filling. The questionnaires for coding were: FETHA- three hundred and sixty eight (368). These include three hundred and sixty two health professionals (362) and six (6) Heads of Departments (units) whereas in General Hospital Onueke, there were eleven (11) health professionals and four (4) heads of departments (units).

In General Hospital Calabar, one hundred and fifty two (152) questionnaires were used. Health professionals were one hundred and forty six (146) while heads of departments (units) were six (6). In Teaching hospital Calabar, the questionnaire were two hundred and thirty six (236) out of which two hundred and twenty nine (229) were health professionals while seven (7) were heads of departments. Therefore, the total number of questionnaires used for analysis were seven hundred and forty eight (748) from health professionals and twenty three (23) questionnaire were from heads of Department making a total of seven hundred and seventy one (771) population.

Fourth stage: selection of tactical managers (for qualitative respondents). To obtain information on management practices at the policy making level in the States, tactical managers were purposively selected. They include Directors in-charge of Administration in each of the two General hospitals; Directors of Planning Research and Statistics (PRS) and focal person human resource for health $(\mathrm{HRH})$ departments in each State Ministry of Health to formed respondants for the key informant interview. In the Teaching Hospitals, Directors of Administration and focal person for human resources for health were purposively selected as key informants. Therefore the total selected number of key informant were twelve (12). However, eight key informants were available for interview.

\section{Instruments for data collection}

Four primary data source for the study were self-administered observational checklist (Appendix 1), two types of questionnaires (Appendices 2 and 3) and key informant interview guide (Appendix 4) used to generate data for this study.

\section{Observational checklist for HRH policy documents}

An observational checklist was used to assess availability of both National and State policies, strategic HRH plans and other HRH documents used as guides in the management of human resource for health. The checklist was made up of twelve (12) items.

\section{Questionnaire for heads of departments (units).}

A fourteen (14) item questionnaire using a rating scale format was used. This instrument elicited information on Human Resource for health management practices on planning. The instrument 
Global Journal of Human Resource Management

Vol.8, No.2, pp.1-32, June 2020

Published by ECRTD-UK

Print ISSN: 2053-5686(Print), Online ISSN: 2053-5694(Online)

comprised of two sections (A \& B). Section A obtained information on the socio-demographic data of the heads of department while section B focused on the implementation of planning practices in their departments. Respondents for this questionnaire were heads of department (Medical, Nursing, Medical Laboratory, Pharmacy, Radiology/Radiography, Dental, Health Information, Physiotherapy and Community Health Extension Workers) in each facility.

\section{Questionnaire for health professionals}

A forty (40)-item structured questionnaire was developed using the rating scale format and administered to healthcare professionals in the selected health departments. The questionnaire consist of two sections, A and B.

Section A: The section elicited response on respondents' demographic chacteristics such as Gender, Health facility, age and designation, which covered four (4) items in all.

Section B: This section comprised of six (6) sub-scales or sub-sections with questions designed to elicit response on the six major variables of the study which highlight the human resource for health management practices in the studied health facilities. This section has a total of 36 questions on a rating scale of 1-5, providing opportunity to rate each response. 1- Being that the practice is not applied, 2- the practice is applied to a little extent, $\mathbf{3}$ - the practice is applied moderately, 4- the practice is applied to a great extent and 5- the practice is applied to a very great extent. The six (6) sub-sections (sub-scales) include;

Sub-scale 1: Human resource for health management practices on recruitment and deployment

Sub-scale 2: Human resource for health management practices on training and development

Sub-scale 3: Human resource for health management practices on retention

Sub-scale 4: Human resource for health management practices on workplace safety and security

Sub-scale 5: Human resource for health management practices on performance management

Sub-scale 6: Human resource for health management practices on human resource information systems

\section{Qualitative: interview guide for tactical managers}

A Twelve (12) item key informant interview guide with open ended questions was used. The respondents for secondary health facilities consisted of Directors In-charge of administration in both General hospitals; Directors of Planning, Research and Statistics and HRH Focal Persons in the State Ministries of Health. In Teaching Hospitals, Directors of administration and HRH focal person of both Cross River and Ebonyi States formed the key informants' population.

\section{The key informant guide consisted of the following sections:}

Section A: Introduction of researcher, note taker, recorder and observer; observation of the ethical principles which entailed presentation of State/facility ethical approval; informing participants of the research purpose and getting verbal informed consent.

Section B: A 12 item key informant guide with open ended question to allow for free expression and probing questions 
Global Journal of Human Resource Management

Vol.8, No.2, pp.1-32, June 2020

Published by ECRTD-UK

Print ISSN: 2053-5686(Print), Online ISSN: 2053-5694(Online)

Section C:closing remark and appreciation of key informant

\section{Validation of research instrument}

Face validation was conducted by my supervisors. Specifically, the instruments were scrutinized based on the relevance of the items in relation to objectives of the study. It was also to ascertain if the items in the instruments measured what they intended to measure and if there would be able to test the research hypotheses.

\section{Reliability of the instrument}

Reliability of research instrument is the consistency with which an instrument measures what it is supposed to measure over time (Bolarinwa, 2015). To determine the reliability of the research instruments, a pre-testing of the instruments was carried out by the researcher. This involved administration of the health professional questionnaire and heads of units' questionnaire to fifty (50) and five (5) respondents respectively from two secondary health facilities not included in the study. The assumption being that the health personnel are similar to the ones who will be used for the actual study in that they have been exposed to similar HRH management practices. Therefore, General Hospitals Ikwo in Ebonyi State and General Hospital Ugep in Cross River State were used for the pre-test exercise.

In each of the health facility involved in the pre-test, the researcher administered the instruments personally to fifty (50) and (5) health professionals and units heads respondents respectively. They were clearly informed that the exercise will be purely for research purpose. After two weeks interval, copies of the same instruments were administered to the same respondents. The retrieved questionnaires were then coded/scored. The two sets of data collected were subjected to analysis using Pearson Product Moment Correlation Coefficient technique to determine the test- retest reliability estimate of the scales in the research instruments. The results of the test - retest analysis presented in Table 1 indicated that the reliability indices ranged from 0.77 to 0.83 . This implies that the indices ranged from between 77 to $83 \%$. Thus, the instruments are reliable enough to be used for the study.

\section{Data collection procedure}

The questionnaire instrument was administered by the researcher to the 796 selected health professionals from two (2) selected secondary health facilities and two (2) tertiary health institutions with the help of four (4) research assistants.For the qualitative data, the key informants participants were visited twice each in their offices. First visit was to seek for permission to interview them and a convenient day and time. The second visit was to carry out the interview which started with the introduction of the research team and purpose of the research. Each interview session lasted 45 minutes to one hour. The team consisted of the researchers (interviewers) 
Global Journal of Human Resource Management

Vol.8, No.2, pp.1-32, June 2020

Published by ECRTD-UK

Print ISSN: 2053-5686(Print), Online ISSN: 2053-5694(Online)

\section{DATA ANALYSIS AND FINDINGS}

Human resource for health management practices on training and development

For clarity, the interpretation was done based on level of healthcare facilities (secondary and tertiary). As presented, human resource for health management practices on training and development seems to differ in the two levels of healthcare facilities (secondary and tertiary) under study. Most of the respondents in the tertiary healthcare facilities reported either moderately or to a great extent to all the statements except for item six in this sub-scale where respondents from secondary healthcare facilities dominated with to a great extent. There are six items in this subscale used to measure management practices on training and development.

In response to the item on provisions for in-service training, most respondents 56(35.7\%) and $31(19.7 \%)$ in the secondary healthcare facilities claimed that there are no provisions for in-service training and that the practice occurred to a little extent in their state/health facility while corresponding responses in the tertiary level of care had 104(17.6\%) and 126(21.3\%) respectively. Percentage of respondents decreased as responses increased towards positivity in secondary healthcare facilities. Therefore, respondents reported 26(16.6\%), 26(16.6\%) and 18(11.5\%) corresponding to moderate practice, practiced to a great extent and to a very great extent respectively. In the tertiary facilities, $146(24.7 \%)$ reported that it was practiced moderately, $134(22.7 \%)$ and $81(13.7 \%)$ submitted that the practice occurred to a great extent and to a very great extent respectively. Responses shown above indicated better practices on provision for inservice training in the tertiary healthcare facilities probably due to the commitment and political will of the Federal government.

In the secondary and tertiary healthcare facilities, 44(28.0\%) respondents and 168(28.4) respondents respectively reported that at a moderate level in-service training is based on identified areas of needs in the healthcare facilities. Also, in the secondary and tertiary healthcare facilities, only $14(8.9 \%)$ and $69(11.7 \%)$ respondents respectively maintained that in-service training based on identified areas of needs in the health facilities was practiced to a very great extent.

On whether staff training addresses current and future needs, 44(28.0\%) respondents out of 157 in the secondary healthcare facilities stated that it was not practiced while only $81(13.7 \%)$ in the tertiary level supported not practiced. Majority in the tertiary healthcare facilities 183(31.0\%) and $135(22.9 \%)$ respondents stated that is was practiced moderately and to a great extent while $40(25.5 \%)$ and $22(14.0 \%)$ in the secondary level agreed that the practiced exist moderately and to a great extent. Again, 21(13.4\%) and 61(10.3\%) respondents in the secondary and tertiary healthcare facilities respectively claimed that the practice was carried out to a very great extent. The responses on this item showed similar trend for both the secondary and tertiary healthcare levels.

For the item that sought to establish if staff skills development programmes are carried out regularly, 37(23.6\%) of each respondents in the secondary healthcare facility reported that it was practiced moderately and to a great extent respectively while $29(18.5 \%)$ respondents claimed that it was practiced to a very great extent. In the tertiary healthcare facilities, $149(25.2 \%)$ claimed that 
Global Journal of Human Resource Management

Vol.8, No.2, pp.1-32, June 2020 Published by ECRTD-UK

Print ISSN: 2053-5686(Print), Online ISSN: 2053-5694(Online)

it was practiced moderately while $135(22.8 \%)$ and $99(16.8 \%)$ respondents claimed that it was practiced to a great and very great extent. The improved positive scores in the secondary healthcare facilities which almost parallel the responses from the tertiary level of care may be related to the training activities of development partners in their areas of intervention with frequent workshops being organised for health professionals.

On whether workshops and seminars are regularly organized to introduce and update staff knowledge and skills, most respondents 42(26.8\%) out of 157 in the secondary healthcare facilities stated that it was practiced to a great extent while 21(13.4\%) reported that it was not practiced. In the tertiary healthcare facilities, 173(29.3\%) respondents stated that it was practiced to a great extent while 63(10.7\%) respondents claimed that it was not practiced at all. These similar responses at both levels of care may again be attributed to trainings, workshops and seminars organized by development partners.

Finally, most respondents $30(19.1 \%)$ in the secondary healthcare facilities claimed that the facilities have accredited training institutions within the catchment area to a moderate extent while majority $156(26.4 \%)$ in the tertiary healthcare facility reported that it is practiced moderately. $32(20.4 \%)$ respondents in the secondary healthcare facilities reported that it was practiced to a little extent while $86(14.6 \%)$ in the tertiary healthcare facilities also claimed that it was practiced to a little extent.

From the responses, it may be derived that human resources for health management practices on training and development in healthcare facilities (secondary and tertiary) had similar trend although higher in the tertiary level, with moderate practice attracting higher scores. However, response on facility has accredited training institution within the catchment area, revealed a higher positive score on practiced to a great extent $(25.5 \%)$ in favour of the secondary healthcare facilities (Table 1). 
Global Journal of Human Resource Management

Vol.8, No.2, pp.1-32, June 2020

Published by ECRTD-UK

Print ISSN: 2053-5686(Print), Online ISSN: 2053-5694(Online)

Similarly, whereas respondents in the secondary healthcare facilities over all reported $217(23.0 \%)$ and $185(19.6 \%)$ as moderate and to a great extent respectively, tertiary healthcare facilities reported $951(26.8 \%)$ and $850(24.0 \%$ ) as moderate and to a great extent respectively (Table $10 \mathrm{~b}$ ). Human resource for health management practices on training and development

\begin{tabular}{|c|c|c|c|c|c|c|}
\hline Practices & $\begin{array}{l}\text { Level of } \\
\text { health facility }\end{array}$ & $\begin{array}{l}\text { Not } \\
\text { practiced }\end{array}$ & $\begin{array}{l}\text { Practiced to a } \\
\text { little extent }\end{array}$ & $\begin{array}{l}\text { Practiced } \\
\text { moderately }\end{array}$ & $\begin{array}{l}\text { Practiced to a } \\
\text { great extent }\end{array}$ & $\begin{array}{l}\text { Practiced to a } \\
\text { very great extent }\end{array}$ \\
\hline \multirow{3}{*}{$\begin{array}{l}\text { There are provisions for in-service training in our } \\
\text { state/health facility }\end{array}$} & Secondary & $56(35.7)$ & $31(19.7)$ & $26(16.6)$ & $26(16.6)$ & $18(11.5)^{*}$ \\
\hline & Tertiary & $104(17.6)$ & $126(21.3)$ & $146(24.7)$ & $134(22.7)$ & $81(13.7)$ \\
\hline & Total & 160 & 157 & 172 & 160 & 99 \\
\hline \multirow{3}{*}{$\begin{array}{l}\text { In-service training is based on identified areas of } \\
\text { needs in the health facility }\end{array}$} & Secondary & $41(26.1)$ & $40(25.5)$ & $44(28.0)$ & $18(11.5)$ & $14(8.9)$ \\
\hline & Tertiary & $71(12.0)$ & $142(24.0)$ & $168(28.4)$ & $141(23.9)$ & $69(11.7)$ \\
\hline & Total & 112 & 182 & 212 & 159 & 83 \\
\hline \multirow[t]{3}{*}{ Staff training addresses current and future needs } & Secondary & $44(28.0)$ & $30(19.1)$ & $40(25.5)$ & $22(14.0)$ & 21(13.4) \\
\hline & Tertiary & $81(13.7)$ & $130(22.0)$ & $183(31.0)$ & $135(22.9)$ & $61(10.3)$ \\
\hline & Total & 125 & 160 & 223 & 157 & 82 \\
\hline \multirow{3}{*}{$\begin{array}{l}\text { Staff skills development programmes are carried } \\
\text { out regularly }\end{array}$} & Secondary & $27(17.2)$ & $27(17.2)$ & $37(23.6)$ & $37(23.6)$ & $29(18.5)$ \\
\hline & Tertiary & $75(12.7)$ & $133(22.5)$ & $149(25.2)$ & $135(22.8)$ & $99(16.8)$ \\
\hline & Total & 102 & 160 & 186 & 172 & 128 \\
\hline \multirow{3}{*}{$\begin{array}{l}\text { Workshops and seminars are regularly organized } \\
\text { to introduce and update staff knowledge and skills }\end{array}$} & Secondary & 21(13.4) & $24(15.3)$ & $40(25.5)$ & $42(26.8)$ & $30(19.1)$ \\
\hline & Tertiary & $63(10.7)$ & $112(19.0)$ & $149(25.2)$ & $173(29.3)$ & $94(15.9)$ \\
\hline & Total & 84 & 136 & 189 & 215 & 124 \\
\hline \multirow{3}{*}{$\begin{array}{l}\text { The facility has accredited training institutions } \\
\text { within the catchment area }\end{array}$} & Secondary & $32(20.4)$ & $26(16.6)$ & $30(19.1)$ & $40(25.5)$ & $29(18.5)$ \\
\hline & Tertiary & $86(14.6)$ & $130(22.0)$ & $156(26.4)$ & $132(22.3)$ & $87(14.7)$ \\
\hline & Total & 118 & 156 & 186 & 172 & 116 \\
\hline
\end{tabular}

TABLE 2

*Percentages are written in parenthesis

Human resource for health management practices on training and development

\begin{tabular}{|c|c|c|c|c|c|}
\hline $\begin{array}{l}\text { Level of } \\
\text { health facility }\end{array}$ & $\begin{array}{l}\text { Not } \\
\text { practiced }\end{array}$ & $\begin{array}{l}\text { Practiced to a } \\
\text { little extent }\end{array}$ & $\begin{array}{l}\text { Practiced } \\
\text { moderately }\end{array}$ & $\begin{array}{l}\text { Practiced to a } \\
\text { great extent }\end{array}$ & $\begin{array}{ll}\text { Practiced } & \text { to a } \\
\text { very } & \text { great } \\
\text { extent } & \end{array}$ \\
\hline Secondary & $221(23.5)$ & $178(18.9)$ & $217(23.0)$ & $185(19.6)$ & $141(15.0)$ \\
\hline Tertiary & $480(13.53)$ & $773(21.8)$ & $951(26.8)$ & $850(24.0)$ & 491(13.9) \\
\hline
\end{tabular}

*Percentages are written in parenthesis

Research Question

Research Question 1

Is there any significant difference in training and development practices between secondary and tertiary healthcare facilities? 
Global Journal of Human Resource Management

Vol.8, No.2, pp.1-32, June 2020

Published by ECRTD-UK

Print ISSN: 2053-5686(Print), Online ISSN: 2053-5694(Online)

Decision rule

The independent $t$-test decision rule states that if the calculated t- value is greater than or equal to $(\geq)$ critical t-value (1.96) from a sample size $(\mathrm{n}=748)$, at 0.05 alpha $(\alpha)$ levels of significance Cohen (1988) established a rule of thumb for evaluating effect size: An effect size (ES) of less than 0.2 is considered as no effect; ES of $0.2 \geq$ to $<0.5$ is considered small effect; ES of $0.5 \geq$ to $<$ 0.8 is considered a moderate effect and an ES of 0.8 and above is considered large effect.

Results:

This result was statistically significant $\mathrm{t}(746)=2.412 ; \mathrm{p}<0.05$. This was because the calculated $\mathrm{t}$-value of 2.412 was greater than the critical t-value of 1.96, at 0.5 alpha $(\alpha)$ levels of significance, $\mathrm{df}=746$. This mean that, there was statistically significant difference in training and development practices between secondary and tertiary healthcare facilities studied. A cursory look at the result shows that tertiary healthcare facilities had a higher mean value $(\mathrm{M}=18.15 ; \mathrm{SD}=5.15)$ which is an indicator of better training and development practices in tertiary healthcare facilities than secondary healthcare facilities $(\mathrm{M}=17.02 ; \mathrm{SD}=5.43)$. This result implies that, the null hypothesis which states that, there is no statistically significant difference in training and development practices between secondary and tertiary healthcare facilities is rejected while the alternate hypothesis is retained. Also, the mean difference was $(\mathrm{MD}=1.13)$

As an additional check, the power of the differences in the means of the two groups (Secondary and Tertiary) healthcare facilities was tested using Cohen's d, this is expected whenever independent samples t-test is applied and significant. However, the effect size (ES) was small revealing that this finding was not substantial in real terms since Cohen's $d=(E S=0.21)$ which is a measure of effect size indicates the proportion of explained or shared variance on the dependent variable (training and development practices), which implies that $21 \%$ of the variance in training and development practices is accounted for by levels of healthcare facilities

TABLE 3

Training and development practices between secondary and tertiary healthcare facilities

\begin{tabular}{|c|c|c|c|c|c|c|c|c|}
\hline $\begin{array}{l}\text { Level of } \\
\text { facilities }\end{array}$ & healthcare & $\mathrm{N}$ & Mean & SD & t-value & P.value & MD & $\begin{array}{l}\text { Effect } \\
\text { size }\end{array}$ \\
\hline Secondary & & 157 & 17.02 & 5.43 & \multirow[b]{2}{*}{2.412} & \multirow[b]{2}{*}{$.016^{*}$} & \multirow[b]{2}{*}{1.130} & \multirow[b]{2}{*}{0.21} \\
\hline Tertiary & & 591 & 18.15 & 5.15 & & & & \\
\hline
\end{tabular}

*significant, $\mathrm{p}<0.05 ; \mathrm{df}=746$; critical t-value $=1.96 ;$ two tailed 
Global Journal of Human Resource Management

Vol.8, No.2, pp.1-32, June 2020 Published by ECRTD-UK Print ISSN: 2053-5686(Print), Online ISSN: 2053-5694(Online)

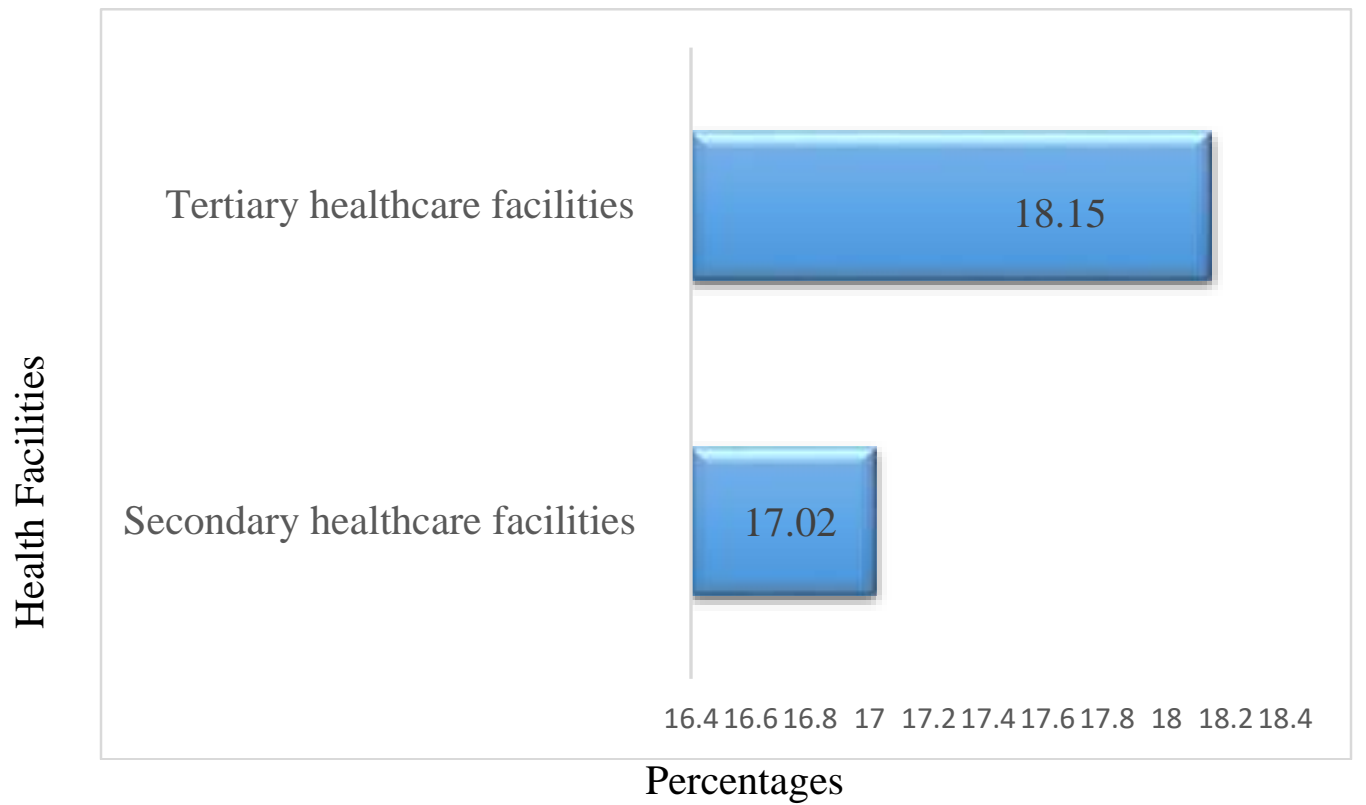

FIG.1: Training and development practices between secondary and tertiary healthcare facilities

\section{Qualitative Result}

Human resource for health management practices on training and development

This objective reveals strategies used for training of health human resource in secondary as well as tertiary healthcare facilities; and also the willingness to train human resource for health. In the state training needs emanate from the State Ministry of Health (SMOH) as stated by a secondary healthcare respondent that;

The Ministry of Health identifies areas for in-service training in areas of need and development partners assist to train staff on different health programmes they intervene.

He continued by stating that there are stipulated pathway before training can be effected, this follows approval from the Ministry in that:

There is a policy on training. The SMOH send circulars to the hospitals indicating the area they need to train the staff.

Occasionally development partners also identify areas/types of health worker they intend to train as stated by a secondary healthcare participant:

The development partners also help in training however, they identify specific areas and type of health personnel they are willing to train.

The participant stressed that in the states there are no provisions for in-service training due to lack of money as stated: 
Global Journal of Human Resource Management

Vol.8, No.2, pp.1-32, June 2020

Published by ECRTD-UK

Print ISSN: 2053-5686(Print), Online ISSN: 2053-5694(Online)

You know for sometimes now the State had stop any form of training due to lack of money to train staff, despite the gross shortage of staff.

Another secondary respondent revealed that their state do not make any provision for training of staff as stated:

The State does not actually encourage staff training because of lack of funds but if at all they are to be trained, it is the responsibility of the Head of service to give approval. Trainings in the State are centrally coordinated by the Head of service. The State rarely sponsor staff even though yearly staff training are budgeted for by different MDAs.

In line with the above another secondary healthcare participant expounded as stated: Unfortunately, for the past 7 years, there has been no effective training of staff. Though training is actually budgeted for and staff do request for training but the story has always been that of no approval. Staff usually apply for training, the hospital will approve without financial release; therefore, staff have to borrow money for their various trainings. The account has several prepared training vouchers but no payment; all we hear every day is 'when there is money we will pay.

However in tertiary institution there are in service training for interested staff as indicated by a respondent from the tertiary healthcare that:

"We are doing well in terms of training including in-service training, particularly here in teaching hospital. Staff normally apply to schools of their interest and when admitted, they apply for sponsorship. Hospital management assist them by allowing them to proceed on study leave with pay.

A tertiary respondent further illuminate support provided by Partners in term of training besides the institution's training arrangement as stated:

Some people were even sponsored by development partners such as: World Health Organization, Last year, the World Bank assisted programme sponsored one staff to study Ophthalmology in India; there are also others who have benefitted from such training.

However, the respondent affirmed that trained staff are expected to come back and serve the institution after training period as narrated:

You know that staff are normally sponsored so that on qualification, they will come back and serve the institution.

In line with this, the respondent reiterated that, employees are usually made to sign bonds which formally binds the trained employee for certain period of time as stated:

Before training, some sign bond, particularly those undertaking study leave with pay. This is to enable them come back and serve the State and health facility after their period of training.

To enumerate further, the respondent said staff training is in line with the principle that staff are trained according to the facility needs and to come back and serve the institution as stated: 
Global Journal of Human Resource Management

Vol.8, No.2, pp.1-32, June 2020

Published by ECRTD-UK

Print ISSN: 2053-5686(Print), Online ISSN: 2053-5694(Online)

staff training is based on facility need on specific specialized areas that the institution need in order to fill the required specialties after their training.

The respondent further stressed that, the institution also provide internal training sessions for staff as stated:

We also carry out some internal training including orientation for new staff depending on where he or she is posted to, so as to appropriately understand the workings of the institution. Presently, there is a proposal on the Chief Medical Director's (CMD) table for staff in-house training and as soon as it is approved, the training will commence.

\section{DISCUSSION OF RESULTS}

Results on Human resource for health management practices on training and development in table 10 shows better practices in the tertiary healthcare facilities. Information obtained on provisions for in-service training showed more positive responses from the tertiary healthcare respondents than the secondary healthcare respondents. In the secondary healthcare facilities, $35.7 \%$ and $19.7 \%$ respondents reported not practiced and practiced to a little extent while only $17.6 \%$ and $21.3 \%$ had corresponding responses in the tertiary healthcare facilities. The t-test analysis shows that there is a significant difference in training practices between the secondary and tertiary healthcare facilities in favour of the tertiary healthcare facilities as the calculated t-value of 2.412 was greater than the critical t-value of 1.96 at 0.05 level of significance with a mean difference of 1.13.The poor or negative responses observed in the secondary healthcare facilities are consistent with the report by Adebajo, Okereke and Friday (2017) who stated that in Cross River State, Nursing and Midwifery schools have not been fully accredited and professional development for health workforce does not exist.

This result is also similar to the findings by the FMOH (2005) who identified lack of continuing education in the secondary healthcare facilities as a serious challenge. This implies that tertiary healthcare facilities implement better practices on training and development than secondary healthcare facilities administered by the State government. This finding was also affirmed by key informant responses from the secondary level participant who verbalized;

You know for sometime now, the State has stopped any form of training due to lack of money for training, despite the gross shortage of staff

Also, another secondary level respondents revealed that their State do not have any provision for training of staff as stated below;

The State does not actually encourage staff training because of lack of funds but if at all they are to be trained, it is the responsibility of the Head of Service to give approval... The State rarely sponsor staff even though yearly staff trainings are budgeted for, by different Ministries, Departments and Agencies (MDAs). 
Global Journal of Human Resource Management

Vol.8, No.2, pp.1-32, June 2020

Published by ECRTD-UK

Print ISSN: 2053-5686(Print), Online ISSN: 2053-5694(Online)

The findings from this study corroborate the assertion by Adeloye, David, Olaogun, Auta, Adesokan and Gandanya et al. (2017) that in Nigeria, several challenges have been reported within the health sector especially in training, funding, employment and deployment of health workforce. Adeloye et al particularly emphasized that there are no provisions for regular clinical training across several healthcare facilities despite credit units needed from this for continuous professional development which is mandatory. The poor practices on human resource for health training and development observed in the secondary healthcare facilities may be attributed majorly to lack of funds and political commitment among other factors by the State government. Again, if the State government places high priority on healthcare, provision would be made to facilitate pre-service and in-service trainings and more so staff professional development. These observed gaps may be a major contributor to health workforce attrition and paucity experienced by secondary healthcare facilities.

The conspicuous differences observed both qualitatively and quantitatively between tertiary healthcare facilities and secondary healthcare facilities may be related to the differences in healthcare services rendered and funding power of the State and Federal government. Interestingly, key informants from both secondary healthcare facilities expressed the fact that development partners do assist in staff trainings but only in their own areas of interest/interventions. It is pertinent to note here that, development partners' area of interest for trainings may not necessarily be the facilities' areas of need. A secondary healthcare participant verbalized thus;

The development partners also help in training however, they identify specific areas and type of health personnel they are willing to train... Before training employees are made to sign bonds.

The areas of similarity in both levels based on key informant responses is that, staff who are to be trained sign bonds to ensure retention and there are elements of development partners' assistance in training and development at both levels of care. However, in the secondary level, training is based on the development partners' areas of interest/intervention while in the tertiary institutions, staff are only trained in the identified areas of healthcare facility needs.

On availability of accredited schools for training of healthcare professionals, responses by healthcare professionals show a fair distribution of schools across both levels. In Cross River State particularly, the efforts of development partners towards accreditation and equipping of schools was obviously identified however there are challenges of accreditation of State-owned schools in both State. This findings in quantitative data which shows high positive responses on availability of accredited schools across both levels of care contradict the assertion by FMOH (2007), Adindu and Asuquo (2013), Adebajo, Okereke and Friday (2017) who assert that most States training institutions do not have accreditation. This quantitative response may be related to the presence of training institutions who may be training last batches of students particularly for schools of nursing and midwifery. It may also have been influenced by the presence of the colleges of health technologies and universities who are training majority of health workforce except for nurses and midwives. 
Global Journal of Human Resource Management

Vol.8, No.2, pp.1-32, June 2020

Published by ECRTD-UK

Print ISSN: 2053-5686(Print), Online ISSN: 2053-5694(Online)

Also, investigations on whether in-service training is based on health facility needs, revealed a high negative response obtained from the secondary healthcare facilities with $26.1 \%$ and $25.5 \%$ reporting not practiced and practiced to a little extent. Comparatively, tertiary healthcare facilities had $12.0 \%$ and $24.0 \%$ having corresponding responses. This may be due to highly specialized services offered in the tertiary healthcare facilities thus making it imperative to train personnels in those areas. Secondary healthcare facilities offer more of general services and has less need for special trainings. The result from the tertiary healthcare facilities is at variance with the assertion of FMOH (2007), Adindu and Asuquo (2013) and Omoluabi (2014) who posit that training of the health workforce in Nigeria is not based on the evidenced - based identified health needs of the healthcare facilities resulting in over production of some cadres and under production of some categories who are critically needed to deliver services.

\section{Implications:}

Information generated from both quantitative and qualitative responses on Human Resource for Health training and Development revealed conspicuous differences between the secondary and tertiary healthcare facilities with better implementation practices in the tertiary healthcare facilities. Findings from this study may demand purposive attention from stakeholders in the health sector and the government of both States to increase their political commitment towards the training and development of their Health workforce. This will ensure a technically fit health workforce to render safe and evidence-based services that meet current trend and the need of the population they serve.

Again, information from this study may spur the government to be committed to implementing budgetary decisions as regards health and health workforce training. Budgeting will not only end in theoretical commitment but it would be practiced to enhance training of human resource for health.

It is hoped that if action is taken as regards information generated from this study, particularly the qualitative data, there would be relative improvement in HRH admission and in-service training with substantive positive effect on quality of healthcare services

\section{CONCLUSION}

Training and development practices based on the findings of this study show poor implementation at the secondary healthcare levels under study which has negative implication on access and quality of healthcare services rendered particularly at the secondary healthcare levels. Furthermore, adequacy of PPE is a challenge in both levels of care which has implication for safety of healthcare professionals and clients

\section{Recommendation:}

1. Furthermore, bi-annual training, retraining and development of the health workforce should be made an area of utmost priority particularly at the secondary level of care. This is important considering the paucity in stock of HRH and emerging challenges emanating from the trend of disease outbreaks and occurrence. 
Global Journal of Human Resource Management

Vol.8, No.2, pp.1-32, June 2020

Published by ECRTD-UK

Print ISSN: 2053-5686(Print), Online ISSN: 2053-5694(Online)

\section{REFERENCES}

Abodunrin, O. L., Adeoye, O. A., Adeomi, A. A. \& Akande, T. M (2014). Prevalence and forms of violence Against healthcare professionals in a South-western city, Nigeria. Sky Journal of Medicine and Medical Sciences, 2(8), 067-072. http://www.skyjournals.org/SJMMS.

Abubakar, U (2015). An overview of the Occupational Safety and Health system of Nigeria, UK, USA, Australia and China: Nigeria Being the Reference Case Study. American Journal of Educational Research, 3 (11), 1350-1358. DOI: 10.12691/education-3-11-3.

Action for Global Health (2011). The Human Resources for Health Crisis: Mapping policies; addressing the Global Health Workforce Crisis: Challenges for France, Germany, Italy, Spain, and the UK. www.actionforglobalhealth.eu

Adebajo, S., Okereke, E \& Joseph, F (2017). Enhancing Frontline health workers abilities to improve $\mathrm{MNCH}$ services in Cross River State through task shifting/sharing. Population Council. www.popcouncil.org

Adebayo, O., Labiran, A., Emerenini, C. F., \& Omonyi, L (2016). Health workforce for 20162030: Will Nigeria have enough? International Journal of Innovative Research 4(1): 9-16. www.sealipaj.org/journals-ci/mar

Adindu, A., Ngobua, S \& Gadanya, M (2016). Human Resources For Health Management training. Trainee Manual. Calabar: Center of Excellence. Human Resources For Health Management Training.

Adindu, A. \& Asuquo, A (2013). Training human resource for $21^{\text {st }}$ century Nigeria health sector. Global Journal of Human Resource Manageement, 1(3),1-11.

Adzei, F. A. \& Atinga, R. A (2012). Motivation and Retention of Health workers in Ghana's District Hospitals. Addressing the Critical Issues. Journal of Health Organization and Management, 26(4), 467-485. http://bos.nj.bpc.baidu.com

Agyapong, V. I. O., Osei, A., Farren, C \& McAuliffe, E (2015). Factors Influencing the Career Chioce and retention of Community mental health workers in Ghana. Journal of Human resource for health 13:56 Doi.10:1186/512960-0150050-2

Agoro, O. O., Osuga, B. O \& Adoyo, M (2015). Supportive Supervision for Medicines Management in Government health facilities in Kiambu County, Kenya: a health workers perspective. Pan African Medical Journal 20(237). Doi:10.11604/pamj.2015. 20. 237. 5872.

Akeem, B. O., Abimbola, A \& Idowu, A., C (2011). Needle Stick injury pattern among health workers in Primary Healthcare facilities in Ilorin, Nigeria. Academic Research International 1: 419-427

Aleke, G (2016). Outdated Nursing Career Progression is a tool for promotion of mediocrity. Nursing World Nigeria: $17^{\text {th }}$ March, 2016. www.nursingworldnigeria.com

Alemu, K. T., Yosef, S. A., Lemma, Y. N \& Beyene, Z. S (2011). An Exploration of Competency Gaps in Human Resource Management in the Health Sector in Ethopia. A Case study of Selected Public Hospitals in Addis Ababa. www.unpan1.un.org/Intradoc

Aluko, O. O., Adebayo, A. E., Adebisi, T. F., Ewegbemi, M. K., Abiodun, T. A \& Popoola, B. F (2016). Knowledge Attitude and Perceptions of Occupational Hazards and Safety Practices in Nigerian Health care Workers. DoI10.1186/513104-016-1880-2. www.BMcresnotes 
Global Journal of Human Resource Management

Vol.8, No.2, pp.1-32, June 2020

Published by ECRTD-UK

Print ISSN: 2053-5686(Print), Online ISSN: 2053-5694(Online)

Amira, C. O. \& Awobusuyi, J. O (2014). Neddle stick injury among health workers in haemodialysis units in Nigeria: a multicenter study. Int.J Occup Environ Med. 2014 5(1): $1-8$

Anyadike, N.O (2014) Effective Strategies for the Improvement of Human and Material Resources Management in the Nigerian Local Government System. International Review of Management and Business Research 3(2) 1264-1274 www.irmbriournal.com

Anyim, F. C., Ikemefuna, C. \& Mbah, S. E (2011).Human Resource Management Challenges in Nigeria Under a global Economy. International Journal of Economics and Management Sciences, 1 (4), 01-11. www.management.Journals.org

Armstrong, M (2009). Handbook of human resource management practices $\left(11^{\text {th }}\right.$ Ed.). India: Repika Press Pvt Ltd.

ASHHRA (2011). Attracting on boarding and retaining employees within the health care industry. ASHHRA e-News Brief. www.naylornetwork.com

Awases, M., Nyoni, J., Bessaoud, K., Diarra-Nama, A., \& Ngenda, C (2010) Developme of Human Resources for Health in the WHO African Region. Current Situation and way Forward. www.aho.afro.who.int

Aziz, I., Kumar, R., Rathore, A \& Lai, M (2015). Work Environment and job satisfaction among health professionals working at a tertiary care hospital of Pakistan. J. Ayub. Med. Coll Abba Habad

Bennibor, S., Ngobua, S., Bailey, R., Alozie, A., Eton, J. \& Pucket, A (2014). Report of training needs assessment for community health workers in South-South Geopolitical Region of Nigeria USAID.

Bolarinwa, O. A (2015) Principles and methods of validity testing of questionnaiare used in social and health science resources. Nigeria Post Graduate Medical Journal, 22(4). 195-201. Doi:104-103/1117-1936. 173959.

Bradley, S., Kamwendo, F., Masanja, H., Pinho, H., Waxman, R., Boostran, C \& McAuliffe, E (2013). Distrct Health Managers' perceptions of supervision in Malawi and Tanzania. Human Resources for Health 11(43): http://www.humanresources-health.com

Bradley, S. \& McAuliffe, E (2009). Mid-level providers in emergency Obstetric and Newborn healthcare: Factors affecting performance and retention witin the Malawian health system. Human Resources for Health. 714.

Capacity Kenya (2009). Technical Brief No.2 : Human Resources Information System for the Health Sector.

CapacityPlus (2012). The iHRIS Suite (human resources information system): Open Source Software. www.who.int/workforcealliance/knowledge/toolkit/21.en/

Castro, A. B., Cabrera, S., Gee, G. C., Fujishiro, K. \& Tagalog, E. A (2009). Occupational and Safety Issues among Nurses in the Philippines. AAOHN Journal 57 (4): 149-157. www.nbi.nlm.nih.gov

Centrifuge group (2018). Human Resource for Health Information System. www.centrifugegroup.com-hrhis

Chankova, S., Nguyen, H., Chipanta, D., Kombe, G., Onoja, A. \& Ogungbemi, K (2006). A situation Assessment of HRH in Public Health Sector in Nigeria. 53. amazonams/com USAID, FMOH/NACA and PHRphs report.

COGNOS (2008). Performance Management in Healthcare. www-07.ibm.com 
Global Journal of Human Resource Management

Vol.8, No.2, pp.1-32, June 2020

Published by ECRTD-UK

Print ISSN: 2053-5686(Print), Online ISSN: 2053-5694(Online)

Cohen, J (1988). Statistical power analysis for the behavioural science, $2^{\text {nd }}$ ed. Hillsdale, N.J: Lawrence Erlbaum

Cross River State Ministry of Health (2017). Cross River State Ministry of Health, Calabar (unpublished).

Cross River State Ministry of Health (2015). Human resources for health policy. Calabar: Ministry of Health.

Cross River State Agency for Control of AIDS (2013). Cross River State Social and Behaviour Change Communication Startegy. Www.sbccvh naca.gov.ng/sites.

Cross River State Ministry of Health (2010). Strategic Health development Plan 2010-2015. Cross River State Ministry of Health. Calabar. www.manaye.org

Cross River State Ministry of Health (2010). Cross River Government Strategic Health Development Plan. http://www.mamaye.org.

Dal Poz, M., Gupta, N., Quain, E. \& Soucat, A (2009). Handbook on Monitoring and Evaluation of Human Resources for Health with special applications for low-and middle-Income Countries.

Das Gupta, M; Gauri, V. \& Khemani, S (2004). Decentralized Delivery of Primary Healthcare Services in Nigeria. Survey evidence from the states of Lagos and Kogi. Washington DC, USA: World Bank development Research Group.

Dessler, G (2008). Human Resources Management. Pearson Prentice Hall, Upper Saddle River.

Dieleman, M \& Harnmeijer, J. W (2006). Improving Health Worker Performance: In search of promising practices. Geneva. World Health Organization. www.who.nt/hrh/resources

Duagalis, J. R; Coons, S. J. \& Plaza, C. M (2008). Best Practices for Survey for Survey Research Reports: A Synopsis for Authors and Reviewers. American Journal of Pharmaceutical Education, 72(1) Article 11. www.ncbi.nm.nih.gov

Dussault, G. \& Dubois, C. H (2003). Human resource for health policies: A critical component of health policies. Journal of Human Resources for Health, 1:1.

Dussault, G. \& Dubois, C. H (2004). Human resources for health policies: A critical component in health policies. Health, Nutrition and population (HNP) Discussion Paper. World Bank Resource Allocation and Purchasing Project www.worldbank.org

Ebonyi State Ministry of Health (2017). Ebonyi State Ministry of Health. Abakaliki (unpublished). Ebonyi State Ministry of Health (2015). Ebonyi State Ministry of Health. Abakaliki (unpublished).

Ebonyi State Ministry of Health (2010). Strategic Health development Plan 2010-2015. Ebonyi State Ministry of Health. Abakaliki. www.mamaye.org

Edet, C., Whyte, M., Ogu, R., Obomanu, G \& Harry, A. M (2017). Use of Technology to manage Health data in Rivers State, Nigeria. A Qualitative study on family planning and Routine health information System. www.measureevaluation.org

Egerega, E (2015). National Health Workforce Registry of Nigeria. AFRIHUB Nigeria limited. www.wiki.ohie.org

EL-Jardali, F., Tchaghchagian, V. \& Jamal, D (2009). Assessment of Human Resources Management Practices in Lebanese hospitals. Journal of Human Resources for Health, 7(84) doi:10.1186/1478-4491-7-84.

Eriki, P., Oyo-Ita, A., Odedo, R., Udoh, A., Omaswa, f. \& Kadama, P (2015). Surgical workforce in Nigeria: Stocke and flow of medical and dental practitioner in Nigeria, with special focus 
Global Journal of Human Resource Management

Vol.8, No.2, pp.1-32, June 2020

Published by ECRTD-UK

Print ISSN: 2053-5686(Print), Online ISSN: 2053-5694(Online)

on healthworkforce training in Cross River State, Africa Centre for Global Health and Social Transformation (ACHEST) FMOH, Nigeria.

Erim, O. E \& Ndoma-Egba (1998). St. Margarets Hospital: One Hundred Years of Dedicated Service to Humanity. Enugu: New Generation Ventures Limited.

Fajana, S., Owoyemi, O., Elegbede, T \& Sheriff, M (2011). Human resource management practices in Nigeria. Jounrnal of Management and Strategy, 2 (2); 57-62. www.sciendu.ca/jms

Federal University Teaching Hospital Abakaliki: Human Resource Unit (2017). (Unpublished).

FMOH (2009). The national strategies health development plan framework (2009-2015). Federal Ministry of Health, Abuja.

FMOH (2007). Draft national human resource for health strategic plan, 2008 - 2012.

FMOH (2006). National Human Resources for Health Policy. Federal Ministry of Health. Abuja. Federal Republic of Nigeria.

FMOH (2005). Strategies for Strengthening the Secondary Health Care (SHC) Delivery System. Abuja: Federal Ministry of Health.

FMOH (2004). Revised National Health Policy. Federal Ministry of Health, Abuja. Fedral Republic of Nigeria.

Forte, A., Margolis, P. S., Crystal, N. G \& Nicholson, E (2015) Human Resources for Health (HRH) Indicator compendium. USAID and Capacity Plus. www.capacityplus.org

Frenk, J., Chen, L., Bhutta, Z. A., Cohen, J., Crips, N., Evans, T. \& Fineberg, H (2010). Health professionals for a new century: Transforming education to strengthen health systems in an interdependent world. The Lancet, 376(9756):1923-1958.

Gberevbie, D. E (2011). An appraisal of staff recruitment and retention policies of Delta State Civil service in Nigeria. Petroleum Gas University Ploiesti Bulletin Vol. Lx111 No. 1/2011. 16-28. Economic Sciences

Global Health Workforce Alliance (2012). Making Health Workers Count. Annual Report. www.who.int/workforcealliance/knowledge/resources/annualreport2012/en/

Global Health Workforce Alliance (2014). Human Resources for Health: Foundation for Universal Health Coverage and the Post-2015 development Agenda: Recife Brazil: www.who.int/workforcealliance

Global Health alth Workforce Alliance (2013) Global Health Workforce Crisi: Key Messages2013 www.who.int/workforcealliance/media

Global Health Workforce Alliance (2008). Human resources for health people: Nigeria. http://www.who.int/workforcealliance/countries.

Groscurth, C (2015). Hospital Performance Management must be Improved Fast. Business Journal, 31, 2015. www.gallup.com/businessjournal/182195

Gupta, B (2013). Human resource Information system (HRIS): Important Element of Current Scenario. Journal of Business and Management, 2319-7668

Henderson, L. N \& Tullock, J (2008) Incentives for retaining and motivating health workers in pPacific and Asia Countries. Human Resources for Health, 6:18. http://www.bcbi.nlm.nih.gov

HeathField, S. M (2016). What is a Human Resources Information System. http://www.thebalance.com 
Global Journal of Human Resource Management

Vol.8, No.2, pp.1-32, June 2020

Published by ECRTD-UK

Print ISSN: 2053-5686(Print), Online ISSN: 2053-5694(Online)

Hong, E. N., Hao, L. Z., Kumar, R., Ramendran, C., \& Kadiresan, V.C (2012). An effectiveness of human resource management practices on employee retention in institutes of higher learning: A regression analysis. International Journal of Business Research and Management, 3(2), 60-79.

InSiGHt Health Consulting Ltd (2016). Lagos State Human Resource for Health (HRH) Assessment Highlights. www.insighthc.org

International Labour Organization (2017). Safety and Health at Work. www/ilo/org/global/topics/safety-and-health-at-work/lang-en/index.htm

International Labour Organization (2014). Social Protectionn Policy Papers. Addressing the Global Health Crisis: Universal Health Protection Policies. Switzerland. www.ilo.org

Intra Health (2018). Nigeria : www/intrahealth.org/countires/nigeria

Intrahealth International (2016) Nigeria. www.intrahealth.org/countries/nigeria

Jacobson, R (2014). Epidemic of violence Against Healthcare workers Plague hospitals. Scientific America. www.scientificamerica.article.com

Jaskiewiez, W., McCaffrey, J., Marsden, P \& Caffrey, M (2015). Strenghtening Human Resources Management and Leadership Legacy series 2 CapacityPlus.

Jomo, J. W. \& Osuga, B. O (2016). Strategies of sealing up health workers distribution in rural public health facilities: A case study of kilifi country, Kenya. International Journal of Scientific Research Publication, 6(4),92-97. www.ijeep.org

Kabene, S. M; Orchard, C; Howard, J. M; Soriano, M. A. \& Leduc, R (2006). The Importance of Human Resources Management in Healthcare: A global context. Journal of Human Resources for Health, 4(20). http://www.human-resources-health.com/context

Karikari, A. F., Boateng, P. A \& Ocansey, E. O. N. D (2015). The role of human resource information system in the process of manpower activities. American Journal of Industrial and Business Management, 5, 424-431.

Kress, D. H., Su, Y. \& Wang, H (2016). Assessment of Primary Health Care Syatem Performance in Nigeria: Using the Primary Healthcare Performance Indicator Conceptual Framework. Journal of health system and reform 2(4). 302-318. Doi.10:1080/23288604.2016.1234861.

Labiran, A., Mafe, M., Onajole, B\& Lambo, E (2008).Human Resources for Health, Country profile-Nigeria. African Health Workforce Observatory, World Health Organization Regional Office for Africa, Congo Brazzaville.

Lehmann, U., Dieleman, M. \& Martneau, T (2008). Staffing remote rural areas in middle and lowincome Countries: a literature review of attraction and retention. BMC Health Serv, Res.8:19

Lunenberg, F. C (2011). Expectancy theory of motivation: motivating by Altering Expectations. International Journal of management, Business and Administration, 15(1),

Lutwama, G. W., Roos, J. H \& Dolamo, B. L (2013). Assessing the implementation of performance management of healthcare workers in Uganda. Journal of health service Research, 13:355.

Manapa, M., Dzimbiri, I \& Maphosa, F (2015). Performance management hurdles in a public health sector organization in Zimbabwe. European scientific Journal, 11(32). www.eujournal.org/index.php/esj

Management Study Guide (2008). Human Resources Management (HRM): Definition and Concept. www.managementstudyguide.com 
Global Journal of Human Resource Management

Vol.8, No.2, pp.1-32, June 2020

Published by ECRTD-UK

Print ISSN: 2053-5686(Print), Online ISSN: 2053-5694(Online)

Manongi, R. N; Marchant, T. C. \& Bygberg (2006). Improving motivation among primary health care worker's in Tanzania: A health worker Perspective. Journal of Human Resources for Health, 4(6). www.ncbi.n/m.nih.gov

Marsden, P., Caffery, M \& McCaffery, J (2013). Human resource management assessment approach. Washington:USAID, Capacity Plus

McCoy, D., Bennette, S., Witter, S., Pond, B., Baker, B., Gow, J., Chad, S., Ensor, T \& McPake, B (2008). Lancet. 371(9613) 675-81.doi:10-16/5040-6736 (08) 60306-2. www.ncbi.nlm/nih/gov

Ministry of Health Kenya (2014) Human Resources for Health Norms and Standards guidelines for Health Sector: Kenya Health Strategic and Investment Plan, 2014-2018.

Mondy, M., Wayne, R \& Bandy, J (2014). Human resource management $\left(13^{\text {th }}\right.$ Ed). Harlow, England: Pearson Educational limited.

Mugo, S., Nyandika, L \& Okibo, B. W (2014). Strategic Human Resource Management in Health Sector in Kenya. Global Journal of Management and Business Research: Administrtion and Management. 14 (7).

Mujeeb, L. M (2012). Importance of best human Resource Management Practices and the need for a Human Resource information system (HRIS) for the public Health sector in Sri Lanka. Sri Lanka Journal of Bio-medical Informatics, 3(2), 55-62. Doi:http://dx.doi.org/10.4038/slijbmi.v3i2. 2449.

Nairaland Forum (2016). Federal Government takes over recruitment of staff. May $8^{\text {th, }} 2016$. www.nairaland.com

National Primary Healthcare Development Agency (2015) Report of Expert Group on Revitalization of Primary Health care in Nigeria: Abuja-Nigeria

National Population Commission (2009). Nigeria Demographic and Health Survey. Abuja. National Population Commission. www.jstor.org/stable/25434601

Ndejjo, R., Musinuzi, G., Yu, X., Buregyeya, E., Musoke, D., Wang, J., Halage, A. A., Whalen, C., Bazeyo, W., Williams, P \& Ssempebwa, J (2015). Occupational health hazards among healthcare workers in Kampala, Uganda. Journal of Environmental and Public Health. Volume 2015, Article ID 913741. www.dx.doi.org/10.1155/2015/913741

Necochea, E., Badlari, M \& Bossemeyer, D (2013). Systemic Management of Human Resources for Health. An Introduction for Health Managers. Baltimore, Maryland:Jhpiego corporation

Nkomazana, O., Peersman, W., Willox, M., Mash, R. \& Phaladze, N (2014). Human resources for health in Bokwana: The result of in-country database and reports analysis. African Journal of Primary Health Care Med., 2014:6 www.pubmed

Nyoni, J., Gbary, A., Awases, M., Ndecki, P. \& Chatora, R (2006). Policies and plans for human resources for health. Guidelines for countries in the WHO African region. WHO.www.who.int/workforcealliance.

Obembe, T. A., Osungbade, K. O., Olumide, E. A., Ibrahim, C. M. \& Fawole, O. I (2014). Staffing situation of primary healthcare facilities in Federal Capital Territory, Nigeria: Implication for attraction and retention policies. American Journal of Social Sciences and Management Sciences, 5(2), 84-90. www.scihub.org 
Global Journal of Human Resource Management

Vol.8, No.2, pp.1-32, June 2020

Published by ECRTD-UK

Print ISSN: 2053-5686(Print), Online ISSN: 2053-5694(Online)

Okafor, C (2017). A reflection on healthcare services in Nigeria and the challenges of medical tourism. Business day April 17 $7^{\text {th }}, 2017$ Public lecture. www.businessdayonline.com

Okechukwu, E. F \& Motshedisi, C (2012). Knowledge and Practice of Standard Precaution in Public health facilities in Abuja, Nigeria. International Journal of Infection Control 8(13) doi: 10.3396/ijic vi3.022.12

Oku, A., Oyo-Ita, A., Glenton, C., Fretheim, A., Eteng, G. \& Ames, H et al (2017). Factors affecting the implemtation of childhood vaccination communication strategies in Nigeria: a qualitative study. BMC Public Health 17 (200): 1-12. DOI 10. 1186/s12889-017-4020-6.

Olaleye, R (2014). Human Resource Management in Healthcare delivery systems. Challenges, trends, and Strategies. Pharmanews global Health Journal, 39(2).

Omoluabi, E. (2014). Needs assessment of the Nigerian health sector. Abuja: International Organization for migration. http:www.nigeria.iom.net.

O’Neill, G. B., Edim, M. E. \& Obarein, B. O. (2014). Casues of prolonged waiting time in public health facilities among healthcare seekers in Calabar Municipal Council of Cross River State. Journal of Research in Humanities and Social Sciences, 4(20),43-47.

Osinbajo, O. A., Adeniji, A. A., Olubusayo, F. \& Heirsmac, T (2014). Compensation Packages: A Strategic Toll for employees' performance and retention. Leonardo Journal of Sciences, 25: 65-84. www.ncbi.nlm.nih.gov

Osungbemiro, B. W., Adejumo, O. A., Akinbodewa, A. A \& Adlosoye, A. A (2016). Assessment of occupational health safety and hazard among government health workers in Ondo City, South West Nigeria. British Journal of Medicine and Medical Research 13 (8) P1-8. http://www.sciencedomain.org/issue/1586.

Parijat, P. \& Bagg, S (2014). Victor Vroom's expectancy theory of motivation: An evaluation. International Research Journal and Management, 2 (9). http///www.irjbm.org

Partnership for Reviving Immunization in Norther Nigeria. Maternal Newborn and Child Health Initiative (2014). Techncal brief: Human resource for health coordinating committee as a mechanism to improve coordinated responses and actions to address HRH issues and challenges. www.prinnmnch.org/document/HRHcoordinatingcommittee

Pearson, K (2009). The causes and incidence of occupational accidents and ill-health across the globe. www.britsafe.org/sites/default

Population Council (2017). Enhancing the Ability of Frontline Health workers to improve Health in Nigeria. Www.popcouncil.org/research

Prytherch, H., Kagone, M., Aninanya, G. A., Williams, J. E., Kakoko, D. C., Leshabari, M. T., Ye, M., Max, M \& Squerborn, R (2013). Motivation and incentives of rural maternal and neonatal healthcare providers: a comparism of qualitative findings from Burkina Faso, Ghana and Tanzania. BMC Health Serv Res 13:149.

Public Services Health and Safety Association (2011). Inspiring Change through innovation. www.wsps.ca

Purity, M., McAuliffe, E., Ogenna, U., Honorati, M \& Henry, M (2017). The Impacts of Supportive Suppervision on the implementation of HRM processes. A mixed-method study in Tanzania. Health Syst Policy Res. 4(1) 47. Doi 10:21767/2254-9137.100066. 
Global Journal of Human Resource Management

Vol.8, No.2, pp.1-32, June 2020

Published by ECRTD-UK

Print ISSN: 2053-5686(Print), Online ISSN: 2053-5694(Online)

Ramadhan, H (2015). Retention Challenges of Human Resources for Health: What are the alternatives incentives for retention of skilled health workers in Uganda health sector. Academic Journals 6(2), Pp.16-23. DOi.10.5897/MPR.2014-0110.

Ranson, M. K., Chopra, M., Akins, S., Dal Poz, M. R \& Bennett, S (2010). Priorities for Research into Health in Low- and Middle- Income Countries. Bull World Health Organization. 88(6): 435-43.doi.10.2471/BLT.09.066290.

Riley, P. L., Zuber, A., Vindigni, S. M., Gupta, N., Verani, A. R., Sunderland, N. L., Friedman, M., Zurn, P., Okoro, C., Patrick, P \& Campbell, J (2012). Information system on human resources for health: A global review.

Salami, B., Dada, F. O., Adelakun, F. E (2016). Human Resources for Health Challenges in Nigeria and Nurse Migration. Policy Politics, \& Nursing Practice 0(0) 1-9. www.sagepub.co.uk/journalspermissions.nav

Sarmah, H. K., Hazarika, B. B \& Choudhury, G (2013). An investigation on effect of bias on determination of sample size on the basis of data related to the students of schools of Guwahati. Journal of Statistical Sciences, 2(1), 33-48. www.reseachgate.net

Senthil, A., Anandh, B., Jayachandran, P., Thangavel, G., Josephin, D., Yamini, R \& Kalpana, B (2015). Perception and prevalence of work related health hazards among healthcare workers in Public health facilities in Southern India. International Journal of occupational and Environmental health 21(1) 74: 81 Doi:10.1179/2049396714/0000000091

Simone, S. D (2015). Expectancy value theory: Motivating healthcare workers. American Journal of Contemporary Research, 5(2),19-23. www.aijcrnet.com

Singh, G \& Negi, K. S (2013). Human resource management practices in large hospitals of Dehrandun, uttarakhand. Global Journal of Management and Business Studies, 3(5), 555560. www.ripublication.com/9Jmbs.htm.

Udogwu, F (2016). Occupational risk and hazard related nurses working in central hospital Warri, Nigeria. Texila International Journal of Nursing, 2 (2). www.texila.journal.com/Nursing

Umar, A. G \& Abdullahi, A. C (2017). Common Occupational health hazards among health care workers in a tertiary health institution in Bida North Central, Nigeria. International Journal of Biomedical Research 08(01). Doi:https://dx.doi.org/10/7439/ijbr

United Nations Foundations (2015). Nigeria Health ICT Phase 2 Field Assessment Findings. Washington DC, USA: United Nations Foundations Pp 8-9, 34-47.

Uneke, C. J., Ndukwe, C. D., Ezeoha, A. A., Urochukwu, H. C \& Ezeonu, C. T (2014). Improving maternal and child healthcare programme using community-participatory intervention in Ebonyi State, Nigeria. International Health Journal of Policy and Management, 3(5), 283 287. Ijhpm.com/article/_2890

Uneke, C., Ezeoha, A., Ndukwe, C., Oyibo, P \& Onwe, F (2012). Enhancing leadership and governance competencies to strenghten health systems in Nigeria: Assessment of organizational HR development. Healthcare Policy, 7 (3) 74-84. www.ncbi.nlm.gov.pmc

Uneke, C; Ogbonna, A., Ezeoha, A., Oyibo, P., Onwe, F. \& Ngwu O (2007). The Nigeria health Sector and human resource challenges. The Internet Journal of Health, 8(1). www.ispub.cox.iJH/8/1/6444.

United States Department of Labour (2016). Guidelines for preventing workplace violence for healthcare and social service workers. www.osha.gov/publications/osha3148 
Global Journal of Human Resource Management

Vol.8, No.2, pp.1-32, June 2020

Published by ECRTD-UK

Print ISSN: 2053-5686(Print), Online ISSN: 2053-5694(Online)

United States Department of Labour (2012). Injury and Illness Prevetion programs. White paper. www.osha.gov/dsg/injuryillness

United States Department of Labour (2011). Employment and training administration (ETA): TAA Program Benefits and Services under the 2011 amendments. www.doleta.org

University of Calabar Teaching Hospital (2017). UCTH, Calabar: Human Resource Unit (unpublished).

Uzochukwu, BSC., Onwujekwe, OE., Soludo, E., Nkoli, E. \& Uguru, N. P (2009). The District Health System in Enugu State, Nigeria: An analysis of policy development and implementation. Enugu: Cosortum for research equitable health system.

Viragi, P. S., Ankola, A. V. \& Hebbal, M (2013). Occupational Hazards in Denitstry- Knowledge, Attitude and Practice of Dental Practioner in Belgaum City. Journal of Pierre Fauchard Accademic (India sect) 27 (3): 90-94

WHO (2006). Working together for health. Work Health Report 2006. Geneva. www.who.int

WHO (2007). Crisis in Human Resources for Health in the African Region. Africa Health Monitor. Vol.7 (1).

WHO (2007). The human resources for health crisis. www.who.int/workforcealliance/ about/hrh_crisis/en/

WHO (2009). National Health Workforce Leaders and Stewardship capacity. www/afro.who.int/en/clusters

WHO (2010). Human Resource for Health Fact Sheet Nigeria. WHO: Africa Health Workforce observatory statistics.

WHO (2013). Transforming and Scaling up health professionals education and training. World Health Organization guidelines 2013. www.apps. who.int

WHO (2013). WHO Nursing and Midwifery Progress Report 2008-2012. www.who.int/hrh/nursing_midwifey

WHO (2015). Nigeria Health Profile. www.who.int/countries/nga/en

WHO (2016). Health workforce, education and training. www.who. int/hrh/education/en/

WHO (2017). Health Services. www.who.int/topics

WHO (2018). Global Health workforce Alliance: Country Responses, Nigeria. www.who.int/workforcealliance

Wiblem, S., Grant, D \& Dery, K (2010). Transitioning to a New HRIS: the Reshaping of Human Resources and Information Technology Talent. Journal of Electronic Commerce Research, 11, 251-267.

Willcox, M., Peersman, W., Daou, P., Diakite, C., Bajunirux, F., Mubangigi, V., Hassan, M., Moosa, S., Phjaladze, N., Nkomazana, O., Khogali, M., Diako, D., Maeseneer, J. \& Maut, D (2015). Human resources for primary healthcare in sub-saharan Africa; Progress or stagnation. Journal of Human Resource for Health, 2015:13-76. www.nebi.nlm.nih.gov/pmc

Yazdi-Feyzabadi, V., Emami, M \& Mehoolhassani (2015). Health information system in Primary Healthcare: The Challenges and Barriers from Local Providers Perspective of an Area in Iran. International Journal of Preventive Medicine 6 (57) 10. 4103/2008-7802-160056. 